University of Nebraska - Lincoln

DigitalCommons@University of Nebraska - Lincoln

To Improve the Academy

Professional and Organizational Development Network in Higher Education

1995

Reflecting Critically On Our Efforts To Improve Teaching and Learning

Ronald A. Smith

Follow this and additional works at: https://digitalcommons.unl.edu/podimproveacad

Part of the Higher Education Administration Commons

Smith, Ronald A., "Reflecting Critically On Our Efforts To Improve Teaching and Learning" (1995). To Improve the Academy. 346.

https://digitalcommons.unl.edu/podimproveacad/346

This Article is brought to you for free and open access by the Professional and Organizational Development Network in Higher Education at DigitalCommons@University of Nebraska - Lincoln. It has been accepted for inclusion in To Improve the Academy by an authorized administrator of DigitalCommons@University of Nebraska - Lincoln. 


\section{Reflecting Critically On Our Efforts To Improve Teaching and Learning}

\section{Ronald A. Smith}

Concordia University

Donald Schön, in The Reflective Practitioner, describes how professionals act to solve the problems they have set for themselves. Peter Senge, in The Fifth Discipline, introduces the ideas of "mental models" and "learning horizons" to describe learning in organizations. These ideas form the basis of a critical analysis of efforts to improve the quality of teaching and learning in higher education over the last 25 years. (An earlier version of this paper was presented at the University of North Carolina Conference on Faculty Professional Development: Faculty Vitality Through Faculty Development. Chapel Hill, NC. June 1992)

I have spent the last 21 years of my career working in higher education as both a faculty member and a faculty developer. My efforts have been focused on trying to help other faculty members and to develop myself. I have always wanted to be a teacher and to be the very best one that I could possibly be. The research suggests that most professors "view teaching as their primary role" (Angelo, 1994, p. 3), want to do a good job, and work hard at improving their effectiveness (Boice, 1992), each in their own way. Most colleges and universities proclaim their commitment to encouraging and supporting excellence in teaching; although many faculty members believe this is only empty 
rhetoric and rarely reflected in their institution's practices, particularly at promotion time (Diamond, 1993; Smith, 1991).

Efforts to enhance teaching and learning excellence appear under different names; for example: faculty development, professional development, personal development, instructional development, or organizational development (Bergquist \& Phillips, 1975; POD Mission Statement, 1991). In this paper I take a careful and critical look at what universities and colleges actually do when they work on developing excellence in teaching and learning, no matter what they call it, and at what individual faculty members do. What is the problem we are trying to solve when we work to improve the quality of teaching and learning in colleges and universities? I believe that what we do depends on what we see as the "problem" to be solved. I will examine three specific areas: 1) professional problem solving in general, how we do it and some of the difficulties we encounter; 2) institutional efforts to improve teaching effectiveness, including a brief historical review; and 3) some of the current efforts in the area of faculty development.

\section{Professional Action as Problem Solving}

Donald Schön, in The Reflective Practitioner: How Professionals Think in Action (1983), describes how professionals (a concept which would include both faculty members and faculty developers) behave when they confront problems, puzzles or surprises, those ambiguous situations where their usually skillful and automatic responses don't seem to be adequate. They first have to frame, or name the problem. Next, they take action, or make moves to explore the situation, or to test some hypothesis about the problematic situation. They then examine the consequences of their actions, they listen to the "talk back" from the situation to see if they have solved the problem they have named. If they have, they move on; if not, they either find new action strategies or they find a new name for the problem, they reframe it. Schon calls this process of framing, acting, and responding to the consequences of our actions "reflection-in-action."

In imposing a structure on the "messes" that we encounter, we actually construct the problem we will attempt to solve. We can be ineffective in solving a problem either because we have chosen the 
wrong action strategy, or because we have named the problem incorrectly. Let's consider some examples. Schön (1983) suggests that in building a road, a civil engineer may attend to drainage, soil stability, and ease of maintenance; while not even seeing the differential effects of the road on the economies of the cities and towns that are near it. He claims that problem finding, defining the problem to be solved, is often the most difficult part of problem solving. What is "the problem" of improving teaching and learning in higher education? It seems clear that it is not a simple problem, since it is repeatedly identified as an important issue to be addressed. This also suggests that our previous efforts have not been as successful as we might like. Often we don't explicitly name the problem we are trying to solve, so it sometimes requires an examination of what we actually do in order to discover the problem we are trying to solve.

We always act to solve the problems we have set for ourselves. How we name a problem depends on a variety of factors: our disciplinary training and background, the roles and responsibilities we have in the organization, our previous experiences and history in similar situations, our interests and skills, and our political and economic perspective. Schön (1987) describes how different professionals might respond to a worry about malnourishment in developing countries. A nutritionist sees a problem of selecting the optimal diet; an agronomist focuses on food production; an epidemiologist frames it in terms of diseases that increase the demand for nutrients or prevent their absorption; a demographer sees population growth which has outdistanced agricultural activity; an engineer looks at food storage and distribution; an economist at purchasing power and the inequitable distribution of land or wealth. It is important to note that the "debates about malnourishment revolve around the construction of a problem to be solved. Debates involve conflicting frames, not easily resolvable - if at all — by appeals to data. Those who hold conflicting frames pay attention to different facts and make different sense of the facts they notice" (Schön, 1987; p. 5).

Universities, like most large organizations, are very complex. Senge (1990), in a book about learning in organizations, identifies two factors, "mental models" and "learning horizons" which can significantly influence our effectiveness as problem solvers. These factors 
can be related to Schön's concepts of framing the situation and responding to consequences of our actions, listening to the "talkback" (see Figure 1).

\section{Mental Models}

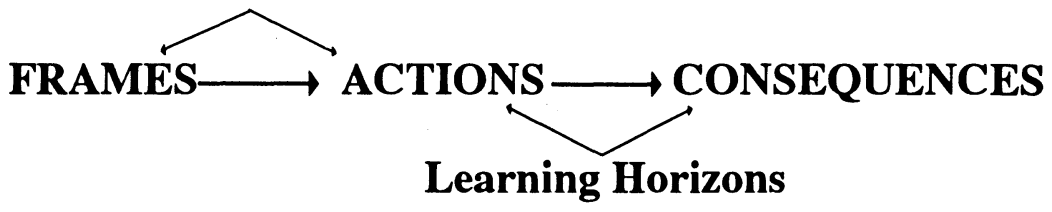

\section{Figure 1. Connecting Senge and Schön}

Although most of us have had considerable experience in our own universities, it is often quite difficult for us to learn from these experiences. The situations are complex and ambiguous; the problems are multi-faceted. No one person in the system ever has all the required information. Like Schön, Senge sees the basis of learning from experience as trial and error: we take action, we see the consequences of our action, then we take a new and different action. But what happens if the consequences of our actions are in the distant future, or in another part of the organization? What is the impact on our ability to learn from our actions if there is a significant delay in the feedback loops in the system? How long will you have to wait to see if improving the system for evaluating teaching has led to an improvement in the quality of teaching? How long will you wait to see if promoting active involvement in your classes leads to increased student learning? When the responses to our actions are beyond our "learning horizon," that is, that "breadth of vision in time and space within which we can assess our effectiveness, it becomes impossible to learn from direct experience" (Senge, p.23).

Each of us approaches the tasks of problem finding and problem solving with our own "mental models," those "deeply ingrained assumptions, generalizations, or even pictures or images that influence 
how we understand the world and how we take action. Very often, we are not consciously aware of our mental models or the effects they have on our behavior" (Senge, p. 8). For example, Parker Palmer (1987) suggests that our epistemology, our personal mental model of what knowledge is and how it is acquired, has a profound impact on how we teach. If we view knowledge as constructed, instead of objective, distanced, analytic, and experimental, then we must create, both in our institutions and in our classrooms, learning communities where this continuous cycle of "discussion, disagreement, and consensus over what has been and what it all means ... (this) arena for creative conflict is protected by the compassionate fabric of human caring itself" (p. 25). Our view of what "good teaching" is will certainly influence what we, either as faculty members or as faculty developers, do to encourage and support its development. Thus, in order to increase our effectiveness in finding and solving the problems of improving the quality of teaching and learning in higher education, we need to bring our mental models to the surface, to hold them up for rigorous scrutiny in conversations which balance advocating our position with invitations to inquiry, where we can reveal how we are thinking, and where we can make our own thinking open to the influence of others.

Before I consider the formal institutionally organized efforts to improve the quality of teaching and learning, I want to invite you, the reader, to take a few minutes to reflect on your own practice. First, think about your own teaching and your efforts to improve it. Write down what you have done, and why you did that? What problem(s) were you trying to solve? Now, consider the problem of improving teaching in your institution. What has or should your institution do to improve teaching, and what is the underlying problem you think these actions are designed to solve?

\section{Institutional Efforts to Improve Teaching}

Let's consider the efforts of universities and colleges to encourage and support faculty development. If you examine these organized and systematic efforts to improve the quality of teaching and learning, you can uncover the implicit definition of the problem(s) they are designed 
to solve. For example, the provision of sabbaticals and study leaves is designed to help faculty members develop and maintain their subject matter mastery. For many people their mental model of teaching is such that knowing the subject is the necessary, and for many it is also a sufficient, condition for quality teaching. Higher education seems to have taken a long time to realize that this is not enough, perhaps an indication of the distance of some learning horizons! The strategy of sabbaticals and study leaves is also supported by the mental models, or myths, that are widely held about the close connections between teaching and research. A connection which is not supported by the empirical research on the issue (Terenzini \& Pascarella, 1994). That most faculty and administrators seem unaware of this research, and don't try to seek it out, suggests still another problem to be solved.

Consider the strategy of student course evaluations. Implicit in the efforts in the 70 s to use students to evaluate teachers, teaching, and courses were some assumptions about professors' lack of knowledge of what their students really thought about what was happening in their classrooms. The mental models of these change agents included the idea that if the students only told the professors which areas needed attention, the professors would change. These mental models probably also included assumptions about change and power: if the faculty did not readily respond to this feedback from the students, they could be embarrassed into changing by the publication of their evaluation results. Or alternatively, the students could avoid the poor teachers and teaching by careful and informed course selection.

In Table 1, I have identified some of the more common approaches to improving teaching used by colleges and universities over the last two decades. The Table can also be interpreted as a reflection of the evolution of our strategies for improving teaching and learning, and as a description of the development of our thinking about the underlying nature of this problem. This evolution in our construction of "the problem to be solved," in the way we name and frame it, and in the development of our strategies to solve it is not surprising. In fact, this evolution through a process of trial and error is necessary, although somewhat frustrating, as well as paradoxical. We cannot really act (to 


\begin{tabular}{|c|c|}
\hline \multicolumn{2}{|c|}{$\begin{array}{c}\text { TABLE } 1 \\
\text { A Brief History of Formal Teaching } \\
\text { Improvement Efforts }\end{array}$} \\
\hline $\begin{array}{c}\text { Moves } \\
\text { What institutions do: }\end{array}$ & $\begin{array}{l}\text { Frames } \\
\text { Because the problem is: }\end{array}$ \\
\hline $\begin{array}{l}\text { 1) Provide sabbaticals, study leaves, and } \\
\text { travel to conferences. }\end{array}$ & $\begin{array}{l}\text { Professors need to know what they are } \\
\text { teaching and be up to date. }\end{array}$ \\
\hline $\begin{array}{l}\text { 2) Audio-visual departments provide films, } \\
\text { T, overheads projectors, computers, laser } \\
\text { disks, etc. }\end{array}$ & $\begin{array}{l}\text { The technologies for teaching have } \\
\text { advanced beyond the book and the } \\
\text { blackboard. }\end{array}$ \\
\hline $\begin{array}{l}\text { 3) Provide consultants on teaching and } \\
\text { instructional design to work with faculty. }\end{array}$ & $\begin{array}{l}\text { Most professors have no training in } \\
\text { teaching, or in using these technologies. }\end{array}$ \\
\hline $\begin{array}{l}\text { 4) Establish research programs/centres on } \\
\text { higher education and circulate the results in } \\
\text { newsletters. }\end{array}$ & $\begin{array}{l}\text { We need to know what works and what } \\
\text { doesn't; and faculty and administrators } \\
\text { need to be informed. }\end{array}$ \\
\hline $\begin{array}{l}\text { 5) Develop questionnaires for students to } \\
\text { evaluate courses and teachers. Student } \\
\text { association published "anti- } \\
\text { calendars". Professors don't know what their } \\
\text { students think about their teaching } \\
\text { effectiveness. }\end{array}$ & Students need information to select wisely. \\
\hline $\begin{array}{l}\text { 6) Offer workshops on life planning, career } \\
\text { transitions, teaching styles. }\end{array}$ & $\begin{array}{l}\text { Professors will work best in the areas that } \\
\text { are personally and professionally satisfying. }\end{array}$ \\
\hline $\begin{array}{l}\text { 7) Work on organizational development, } \\
\text { develop mission statements, procedures for } \\
\text { evaluating teaching; e.g., teaching } \\
\text { portfolios. }\end{array}$ & $\begin{array}{l}\text { If you want professors to work on their } \\
\text { teaching, you need to recognize and reward } \\
\text { good teaching. }\end{array}$ \\
\hline $\begin{array}{l}\text { 8) Provide consultants on team building and } \\
\text { conflict management, and training for chairs } \\
\text { and other administrators. }\end{array}$ & $\begin{array}{l}\text { Professors cannot concentrate on their } \\
\text { teaching if their department is not } \\
\text { functioning well. }\end{array}$ \\
\hline $\begin{array}{l}\text { 9) Provide assistance to both faculty and } \\
\text { students for innovative curriculum projects; } \\
\text { e.g., McMaster's Medical School, Harvard's } \\
\text { New Pathway. }\end{array}$ & $\begin{array}{l}\text { Individuals will be most interested in and } \\
\text { open to change when they are developing a } \\
\text { new program. }\end{array}$ \\
\hline $\begin{array}{l}\text { 10) Provide orientation programs for faculty } \\
\text { who are new to the institution. }\end{array}$ & $\begin{array}{l}\text { Teaching at this institution is different from } \\
\text { teaching anywhere else. }\end{array}$ \\
\hline $\begin{array}{l}\text { 11) Provide training programs for teaching } \\
\text { assistants (and conferences for people who } \\
\text { run these programs). }\end{array}$ & $\begin{array}{l}\text { Training to teach should be part of graduate } \\
\text { training. }\end{array}$ \\
\hline & \\
\hline
\end{tabular}


improve teaching) unless we know what we are doing. Yet, we cannot really know what we are doing (what the problem is and what will solve it), unless we act.

An examination of Table 1 can provide some insights into a) the nature of professional problem solving, b) the process of reflectionin-action, and c) the necessity of learning from experience. When our actions do not produce the intended consequences, we see ourselves as not being effective, as making errors. Learning to be more effective requires that we detect and correct these errors, these gaps between what was intended and what was produced. Sometimes that learning involves changing our action strategies; sometimes it involves changing the names or frames we have for the problem to be solved. Schon, in his writings $(1983,1987)$, is talking about how individuals learn from experience, but his ideas can also be applied to describe how larger groups, such as departments, universities, or professional associations might change over time. Since all groups are collections of individuals, any change in the group requires change in the individuals. (Argyris 1982, 1985, 1993; Argyris and Schön 1978; and Senge 1990 discuss in detail the relationship between individual and organizational learning.)

Each of us, based on our own experiences and our own mental models of how the world of higher education works, will have our own versions of this story. When we, either as faculty developers or as individual faculty members, thought that improving teaching meant staying up-to-date with the subject matter, we looked to sabbaticals and study leaves. When we did not achieve the consequences we intended, when the quality of teaching did not improve, we reframed the problem to focus more directly on teaching. Our new solution was to provide a variety of teaching aids. When it was discovered that people weren't using them very much, or weren't using them effectively, training and expert support were provided.

When the consequences of our actions are interpreted as indicating that our goals are not being achieved, that professors are still teaching in much the same way as they have for the last three hundred years, a new strategy is implemented. Perhaps what is needed is more and better information about what has worked and what has not, either from the research literature, or from the students in the classrooms. 
Since each of these strategies for change represents an intervention into a complex system, it is hard to know exactly what is the impact of any particular strategy. How would we collect the data in order to know if circulating a newsletter, or the results of student evaluations has improved teaching and learning on our campus? We often hear the complaint from administrators, from faculty members, and sometimes from faculty developers, that we are "preaching to the choir," only the good teachers respond. The faculty members who really need to improve never participate in the programs. Thus, the name of the problem changes to: How do we get more faculty to want to work on their teaching? Some of the problem-solving strategies have focused on improving the recognition and reward (or punishment) system, on organizational development. Others have focused on the personal development side, on career development and life planning.

The last three moves described in Table 1 seem to bypass this issue and define the problem differently. The previous problem-solving strategies can be interpreted as activities and programs to support, if not force, faculty members to change their behavior, and were usually designed to affect all faculty members. The last three strategies ( 9, $10, \& 11)$ try to respond to faculty members, or future faculty members, at the moment when they should be most interested in learning, by addressing more specific needs. When faculty members embark on a new curriculum, move to a new institution, or take on new responsibilities (such as being a TA or TA supervisor), they may be more responsive to faculty development initiatives.

Certainly, few colleges or universities have tried all of these approaches, but at most institutions you can find some selection of these activities. Lindquist's original ordering reflects the general sequence of the development and implementation of these services. The faculty development programs or centers that have been created more recently usually offer a variety of services, reflecting the local definitions of the specific problems to be solved. Some developers believe that the best solution is to provide faculty members with access to a range of resources, together with the opportunity and responsibility to choose, each according to his/her own personal definition of the problem to be solved. 


\section{How Well Have We Achieved Our Goals?}

How successful have we been in improving the quality of teaching and learning? How well have these programs worked? Have the faculty responded? Sadly, there is not very much good data on the response of the faculty to these formal efforts to improve teaching and learning (Angelo, 1994). Weimer \& Lenze (1991) conclude their review of the literature with "more research must be undertaken.... instructional interventions are being used with virtually no empirical justification as to their effectiveness" (p. 327). Faculty/instructional developers have been working on this project for quite some time, since at least the late 60s. In 1972, Alexander and Yelon were able to report on the activities of only 16 centers or programs. The first POD conference was held in 1976. It was also in 1976 that Centra reported that 1044 institutions in the US had some set of practices for faculty development or instructional improvement. In 1978 Lindquist was writing about different approaches to improving instruction, and by 1981 Bergquist and Phillips had published the third volume of their Handbook for Faculty Development.

While numerous programs to support and encourage the improvement of teaching have been developed over the last 25 years, it is still not clear that teaching well really matters. In 1993, Robert Diamond, in Recognizing Faculty Work: Reward Systems for the Year 2000 stated it bluntly: 'the focus on research and publication and the mad dash for federal funds and external grants has diverted energies away from important faculty work and has had a direct and negative impact on the quality of classroom instruction" (p. 8). In 1991, Stuart Smith in the Report of the Commission of Inquiry on Canadian University Education, which had been established by the Association of Universities and Colleges of Canada, declared that "teaching is seriously undervalued at Canadian universities and nothing less than a total recommitment to it is required."(p. 63.) He declared that "the Commission perceives a deep cynicism among the faculty concerning the real importance accorded to teaching," and that there is a deep concern that "the quantity of research publications is more important to the careers of university professors than is the excellence of their teaching" (p. 31). Furthermore, "innovation, either in the form of technol- 
ogy or in the use of novel teaching methods, is disappointingly uncommon."

One could conclude from this analysis that there is a significant gap between what is intended and what is produced. Is it that the "improvers" haven't yet used the right strategy (e.g., they haven't clearly disseminated what is known about effective teaching, or developed the right workshops, or invented the right evaluation forms for student feedback); or is it that they still haven't figured out what the real problem is (i.e., they are trying to solve the wrong problem)? Before considering some of the most recent institutional solutions to the problem of improving the quality of teaching and learning, I want to examine briefly what individual faculty members do in this regard.

\section{Faculty Perspectives on Improving Teaching}

In study after study the majority of faculty members continue to report that teaching is a very significant and satisfying part of their professional lives, and that they work hard at improving their teaching (Boice, 1992). At most institutions faculty would like to see more of a balance between teaching and research, as opposed to the current tilt towards research (Gray, Froh, \& Diamond, 1992). When faculty work on their teaching, what do they do? What problem(s) do faculty members try to solve when they work on their teaching? Smith (1984) reports that most faculty seem to have framed their problem in terms of the course content or materials, focusing their attention on organizing it better, getting it more up to date, and arranging to present it more clearly on slides or transparencies. And they only seem to work on those problems they think they can solve. After all, they are very smart people! Faculty often define their problem as "too much content, too little time"; so they concentrate on arranging the best material in the best package for the most efficient transmission. This is often seen as a continuous task, one on which they need to work throughout their entire career.

If you examine their analysis of the source of their difficulties in being more effective teachers, it reflects problems within the framework of this transmission metaphor; that is, the "receivers" or the "channel" are flawed in some way. Faculty identify students who are 
unprepared, unmotivated, or just too diverse; there are too many students, the room is poor, or the time of day is not just right. These problems are seen either as unsolvable by the individual professor (e.g., the general decline in reading ability or SAT scores) or as someone else's responsibility (e.g., admissions, scheduling, physical plant). Hence, many faculty are left feeling helpless and disempowered. The apparent lack of institutional response to their versions of these problems is interpreted by the faculty as further evidence that teaching doesn't really matter. In contrast to this view, I want to now turn to an examination of some of the current thinking by some parts of the higher education community about the problem(s) which need to be solved in order to improve the quality of teaching and learning.

\section{Some Current Thinking about The Problem}

In 1979 Freedman, based on interviews with over 700 faculty, concluded:

[Professors'] discussions of educational programs or reforms proceed as if education had no discipline, no organized systematic body of theory and knowledge and no need for such a discipline. In short, faculty approach teaching and education as would any intelligent adult chosen at random - on the basis of some opinion and reading and some knowledge based on experience.... Very few faculty members can define the basis on which they evaluate themselves or can offer any rationale for what they do in the classroom. It is apparent most of them carry on in the way they learned as students. Not only does traditional academic culture ignore basic educational issues, it does not even possess the concepts to deal with them (p. 8).

How much evidence is there that the situation has changed significantly in the last 25 years? Patricia Cross begins her 1990 article "Teachers as Scholars" by commenting how intellectually challenging teaching can be, while observing that it is generally "practiced at such a primitive level. Professionally it stands where medicine stood a hundred years ago.... Most doctors learned their trade by apprenticeship, in which ignorance as well as experience was passed along 
generation to generation - much as potential teachers learn their trade today" (p. 3).

She ends that article with an analogy to farming to describe the situation:

We don't really know why some students thrive and others don't. We often don't observe whether the seeds we plant take root. We can't detect wilt. And even when we see the beginning signs of boredom or disengagement, we don't take immediate steps to treat it because we assume it's the nature of the plant to wilt - or more often, perhaps because we don't know how to treat wilt, or we don't have time.

\section{Focus on Student Learning}

Implicit in her comment is the suggestion that in order to improve teaching we need to pay attention to learning. Other writers have also recently echoed this concern. We should focus on enhancing the productivity of learning (Johnstone, 1993). "Most faculty-development efforts focus primarily on improving teaching - and only secondarily, if at all, on improving learning" (Angelo, 1994, p. 4). Knapper (1995) is more direct: "The bottom line is learning" (p. 70). Guskin (1994) suggests that we should restructure faculty work "to maximize essential faculty-student interaction, integrate new technologies fully into the student learning process, and enhance student learning through peer interaction" (p. 19). His focus is on connecting the different types of learning expected from students (the accumulation of information, skill development, and conceptual development) with the most appropriate use of the institutional resources of faculty time, peers, and technology for each type of learning.

There are certainly differences of opinion about what needs to be done. Do faculty need to radically reconceptualize the task of teaching, as Guskin and others argue? Metaphorically speaking, do we need to design a new means of transportation? Or will helping the old horses run faster be good enough? In general, the culture of the academy doesn't seem to include much discussion of differences in learning styles, or of adapting teaching to individual differences. Many faculty seem to be saying: "send me students who can learn from the way I know how to teach," rather than "I need to learn how to teach the 
students I am sent." Guskin is not overly optimistic about the pace of these changes: "Restructuring the role of faculty will, at first, prove to be a monumental undertaking. All of the incentives seem to be against doing so - except in the end, survival" (p. 16). Will the faculty, if not the colleges and universities, just be by-passed, if we/they refuse to respond?

Ramsden's (1992) perspective is quite clear. He states: "To teach is make an assumption about what and how the student learns; therefore to teach well implies learning about students' learning" (p. 6). At the core of his approach is a body of research, conducted primarily in Great Britain and Australia, on the connections between various teaching practices and "deep versus surface learning." Like Guskin's radical restructuring of faculty work, Ramsden also advocates dramatic changes, while still keeping the faculty member at the center of the improvement project. Faculty need to move beyond their amateur approach to teaching in higher education towards becoming more professional. They need to establish a theoretical base which will inform and support their practice. He states: "the professional authority of the academic-as-teacher should rest on a body of didactic knowledge. This comprises knowledge of how the subject he or she professes is learned.... the key to improving teaching is changing the way in which the process of education is conceived by its practitioners" (Ramsden, 1992, p. 9). Unfortunately, he is less clear about how to get individual faculty members to rethink their roles, to attend to this research, and to incorporate it into their practice, beyond suggesting that we need to change our evaluation procedures, an idea which many others have also recommended (Wright \& O'Neil, 1995). Yet, how do we get that to happen? Before we consider that issue directly, let's examine in more detail this idea of the professional responsibility of the faculty member in terms of teaching.

Is it enough to do research on teaching and learning and to disseminate the results of that research to faculty members? It certainly seems clear that more research is needed, as well as newsletters and journals to disseminate it. Many campuses publish their own newsletters on teaching, and nationally we now have The Teaching Professor, To Improve the Academy, and The Journal of Excellence in College Teaching, to name but a few. However, are they being read? To what 
extent do they influence practice? Based on the slow pace of change, it seems clear that our analysis of the problem needs to be more subtle and sophisticated. Angelo (1994) has suggested a reframing of the problem, we need to move from "Faculty Development" to "Academic Development." Angelo and Cross (1993) have argued that we need research to improve teaching and learning, but the research we need can and should be done by individual teachers; they should become "classroom researchers." This is similar to Ramsden's suggestion that faculty members need to become more professional about our teaching roles. It is also quite clear that faculty developers need to become more professional in terms of carefully documenting in a credible manner "the wisdom of practice and the voice of experience" (Weimer \& Lenze, 1991, p. 327). Light (1990 \& 1992), with the Harvard Assessment Seminars, created opportunities for groups of professors to assess the impact of their practices on their own students. These seem like worthwhile ideas and successful projects, they provide methods, techniques, and opportunities for faculty to learn more about their own teaching effectiveness, and they go beyond some of our earlier strategies; e.g., providing the results of student course evaluations and disseminating traditional educational research. Will these ideas only work well for the faculty members who are truly interested in teaching? Are they powerful enough to address the problem that teaching does not seem to be taken seriously enough on far too many campuses?

\section{Create a Culture of Teaching}

Perhaps the problem is: How do we change the very culture of the academy; that is, change the place of teaching in higher education? Some people have suggested that we need awards to recognize excellent performance. In the United States, there is the CASE outstanding teacher competitions, as well as the Hesburgh Award for faculty development. In Canada, the $3 \mathrm{M}$ Teaching Fellowship was created as a national award to honor excellence in teaching and contributions to teaching improvement. Since it was established in 1986, 100 faculty members have been honored. In 1991, the University of British Columbia awarded twenty-four $\$ 5000$ prizes to faculty in recognition 
of their commitment to teaching. Other people have suggested that we need to create opportunities to talk about teaching. The American Association for Higher Education has taken a leadership role through its recent national conference themes: "Taking Teaching Seriously," "Stand and Deliver," and "Celebrating Teaching." Their "Teaching Initiative" now includes the annual "Forum on Exemplary Teaching" as part of their national conference. AAHE is also sponsoring projects on cases about college teaching and the peer review of teaching. All of these programs are designed to create opportunities and vehicles for professors to come together to talk about their teaching, a rare occurrence on most campuses. We need to know more about what type of talking will lead to improved teaching and learning.

What is required (the problem to be solved) and what is being recommended (the solution to the problem) are nothing short of a radical transformation of the culture of the academy, including our fundamental conceptions of teaching and scholarship. But how do we accomplish this? Many of the most recent interventions seem to be designed to directly address this problem of taking teaching seriously. We are returning to the issue of recognizing and rewarding teaching with renewed vigour and sophistication, and with new mental models. Russell Edgerton (1990), President of AAHE, has argued that teaching is not a derivative or afterthought to research, but that it reflects the highest form of understanding:

There is more to teaching than simply knowing the subject and talking about it; that's the easy part. The difficult part is finding the words, the metaphors to represent the ideas of the discipline to those who don't already understand it. How do you represent the idea of electricity to a freshman? Is it like water flowing through pipes, cars on a highway, an assembly line? Is there a better analogy? Viewed this way, effective teaching becomes the highest form of understanding. Aristotle's strictest measure of whether or not someone really knew their subject was whether they could turn around and teach it.

The connections between teaching and scholarship are being redefined. The Carnegie Foundation for the Advancement of Teaching in a report entitled Scholarship reconsidered: Priorities of the professoriate, proposed a re-conceptualization of scholarship to include: the scholarship of discovery, of integration, of application, and the schol- 
arship of teaching. Shulman (1993, November/December) has suggested that we need to move beyond our "pedagogical solitude" toward treating teaching as community property. This requires artifacts which can capture the complexity of teaching, and peers who are willing and able to review these materials. If that is the problem to be solved, then strategies such as teaching portfolios (Edgerton et al., 1991) and the Peer Review of Teaching Project (AAHE, 1995) seem to make good sense. Shulman (1993, January) has set the problem to be solved as follows:

[To] organize the evaluation of teaching so that the very procedures we employ raise the likelihood that teaching gets treated seriously, systematically, and centrally in the lives of individual faculty and institutions ... to use procedures from which teachers learn how to teach better ... (and) to think about the reward system and think about the evaluation of teaching and therefore about such strategies as portfolios, not simply as psychometric devices to increase the accuracy of our evaluations, but as culture-producing strategies that change the fundamental ways in which we live and think (pp. 9-10).

\section{Learning to Close the Gaps}

Rethinking the issues of faculty roles and rewards has been the subject of three national conferences sponsored by AAHE. Various disciplinary associations are beginning to work on defining the scholarship of teaching in each of their areas (Adams \& Roberts, 1993). Will these strategies be successful? Has the problem to be solved been framed more accurately this time around? Shulman (1993, November/December) has argued that in the academy we only take seriously that which is reviewed by peers. But, the faculty are the academy (or at least one very important part of it). What leads us to create and maintain systems in our colleges and universities where teaching is not taken seriously, in spite of the rhetoric to the contrary? Perhaps the very first step that needs to be taken is to acknowledge the gap between what we say and what we do. We need to identify the ways that our own behavior, either as faculty members or as administrators, has contributed to creating and maintaining a climate and culture where teaching doesn't seem to matter much. This recognition and 
acknowledgement of the gap between where faculty think their institutions are going versus where they think their institutions should be going in terms of the balance between undergraduate teaching and research is an important first step (Gray et al., 1992).

What leads professors to say that teaching is an important and satisfying part of their professional lives, yet to rarely talk to their colleagues about it? What leads faculty members to rarely recommend their colleagues for promotion on the basis of teaching; to rarely demand, as part of the hiring process, that each candidate be required to teach a lesson or prepare a course outline? Why is there is no equivalent of medicine's grand rounds where faculty members discuss their difficult cases in presenting concepts, or the exciting experiments they are conducting in their teaching? We seem to behave as if teaching is "so straightforward that it requires no special training, and yet so complex and idiosyncratic that mere training could never meet its extraordinary demands" (Group for Human Development in Higher Education, 1974; p. 14). It is the faculty members who do not take teaching seriously, who do not see it as "one of the most profoundly intellectually challenging aspects of our jobs", to quote Cross. However, just saying it is won't make it so. Why do we believe that inviting, or demanding, that faculty members create teaching portfolios will change our culture? Can our behavior until now be explained by the mere absence of this good idea? Or is the problem more complicated?

Most faculty come to the classroom with no training for teaching beyond expertise in the discipline. The discrepancy between what is espoused, that teaching matters, and what is practiced, is glaring. Yet, this gap is not discussed in any productive way. Parker Palmer (1992) suggests an alternative model to the organizational approach to change. He calls it the "movement approach," where individuals decide to live "divided no more." He says: "Most of us know from experience what a divided life is. Inwardly we feel one sort of imperative for our lives, but outwardly we respond to quite another" (p. 12). As faculty members, if teaching really matters to us, we need to find the courage to act through coming to realize "that even if teaching is a back-of-the-bus thing for [our] institutions, it is a frontof-the-bus thing for [us].... Caring about teaching and about students brings [us] health as persons, and to collaborate in a denial of that is 
to collaborate in the diminishment of [our] own lives"(p. 13). We need to refuse to respond to the pressures of our institutions by coming to realize that "there is no punishment worse than conspiring in a denial of one's own integrity" (p. 17). Is there a movement towards taking teaching seriously? Has it just begun, or is it well under way? It remains to be seen whether or not any our "new strategies" will be able to solve the problems we have set for ourselves. What exactly is the problem to be solved? Is it to get more of the faculty to take their teaching responsibilities seriously? Or is it to help those faculty who already do care about their teaching to find a way to live more satisfying and rewarding academic lives?

If we are to take teaching and faculty development seriously, if we are to become more professional about our work, we need to create "learning organizations" which can identify and correct the gaps between what we wish for and what we create. No faculty member, faculty developer, or administrator deliberately sets out to create an organization where individuals feel that their contributions are not recognized and rewarded. We need to be able to create the conditions in our institutions where the gaps between what we espouse and what we produce can be identified and corrected. It is our challenge as scholars and our responsibility as professionals. In our roles as individuals concerned with faculty development, what actions will we take, what problems will we try to solve? To the extent that we can make our frames public, bring our mental models into our consciousness, and into our conversations, I believe we will be in a better position to be able to act more effectively as faculty developers. The goal is not to reach a consensus, but rather to engage in a discussion which will keep the inquiry going.

\section{References}

Adams, B. E. \& Roberts, A. O. (1993). Differences among the disciplines. In R. W. Diamond \& B. E. Adams (Eds.), Recognizing faculty work:: Reward systems for the year 2000. New Directions for Higher Education, No. 81. (pp. 101-114). San Francisco: Jossey-Bass.

Alexander, A. T. \& Yelon, S. L. (1972). Instructional development agencies in higher education. East Lansing, MI: Continuing Education Service.

American Association for Higher Education. (1995). From idea to prototype: The peer review of teaching. A project workbook. Washington, DC: AAHE. 
Angelo, T. A. (1994, June). From faculty development to academic development. AAHE Bulletin, pp. 3 - 7.

Angelo, T. A., \& Cross, K. P. (1993). Classroom assessment techniques: A handbook for college teachers. (2nd ed.). San Francisco: Jossey-Bass.

Argyris, C. (1982). Reasoning, learning and action: Individual and organizational. San Francisco: Jossey-Bass.

Argyris, C. (1985). Strategy, change and defensive routines. New York: Harper Business.

Argyris, C. (1993). Knowledge for action: A guide for overcoming barriers to organizational change. San Francisco: Jossey-Bass.

Argyris, C. \& Schon, D. A. (1978). Organizational learning. Reading, MA: AddisonWesley.

Bergquist, W. H. \& Phillips, S. R. (1975). A handbook for faculty development. (Vol. 1). Washington, D.C.: Council for Independent Colleges.

Bergquist, W. H. and Phillips, S. R. (1981). A handbook for faculty development. (Vol. 3). Washington, D.C.: Council for Independent Colleges.

Boice, R. (1992). The new faculty member: Supporting and fostering professional development. San Francisco: Jossey-Bass.

Centra, J. A. (1976). Faculty development practices in U.S. colleges and universities. Princeton, NJ: Educational Testing Services.

Diamond, R. M. (1993). Changing priorities and the faculty reward system. In R. M. Diamond \& B. E. Adams (Eds.) Recognizing faculty work: Reward systems for the year 2000. New Directions for Higher Education, No. 81. (pp. 5-12). San Francisco: Jossey-Bass.

Cross, K. P.(1990, December). Teachers as scholars. AAHE Bulletin, pp 3-5.

Edgerton, R. (1990, Winter-Spring). Forward to aristotle: Teaching as the highest form of understanding. Teaching Excellence; $A$ Publication of the Professional and Organizational Development Network.

Edgerton, R., Hutchings, P., \& Quinlan, K. (1991). The teaching portfolio: Capturing the scholarship of teaching, Washington, DC: American Association for Higher Education.

Freedman , M. (1979). Academic culture and faculty development. Berkeley: Montaigne.

Gray, P. J., Froh, R. C., Diamond, R. M., (1992). A national study of research universities: On the balance between research and undergraduate teaching. Syracuse: Center for Instructional Development, Syracuse University.

Group for Human Development in Higher Education. (1974). Faculty development in a time of retrenchment. New York: Author \& Change Magazine.

Guskin, A. E. (1994, September/October). Reducing student costs \& enhancing student learning part II: Restructuring the role of faculty. Change Magazine, pp. 16-25.

Johnstone, D. B. (1993, December). Enhancing the Productivity of Learning. Change Magazine, pp. 3-8. 
Knapper, C. K. (1995). Understanding student learning: Implications for practice. In W. A. Wright and Associates, Teaching improvement practices (pp. 58-75). Bolton, MA: Anker.

Light, R. J. (1990). The Harvard Assessment Seminars: Explorations with students and faculty about teaching, learning, and student life. Cambridge, MA: Harvard University.

Lindquist, J. (1978). Designing teaching improvement programs. Berkeley, CA: Pacific Soundings.

Palmer, P. J. (1987, September/October). Community, conflict, and ways of knowing: Ways to deepen our educational agenda. Change Magazine, pp. 20-25.

Palmer, P. J., (1992, March/April). Divided no more: A movement approach to educational reform. Change Magazine. pp. 11-17.

POD mission statement. (1991). To Improve the Academy, 10, viii.

Ramsden, P. (1992). Learning to teach in higher education. London: Routledge.

Schon, D. A. (1983). The reflective practitioner: How professionals think in action. New York: Basic Books.

Schon, D. A. (1987). Educating the reflective practitioner. San Francisco: Jossey-Bass.

Senge, P. M. (1990). The fifth discipline: The art and practice of the learning organization. New York: Doubleday/Currency.

Shulman, L. S. (1993a, January). Displaying teaching to a community of peers. Address presented at the American Association of Higher Education Conference on Faculty Roles and Rewards, New Orleans, LA.

Shulman, L. S. (1993, November/December). Teaching as community property: Putting an end to pedagogical solitude. Change Magazine, pp. 6-7.

Smith, R. A. (1984). Faculty perceptions of teaching improvement. Unpublished doctoral dissertation, McGill University, Montreal.

Smith, S. L. (1991). Report: Commission of inquiry on canadian university education. Ottawa, ON: Association of Universities and Colleges of Canada.

Terenzini, P. T. \& Pascarella, E. T. (1994, January/February). Living with myths: Undergraduate education in America. Change Magazine. pp. 28-32.

Weimer, M., \& Lenze, L, F. (1991). Instructional interventions: A review of the literature on efforts to improve instruction. In J. Smart (Ed.), Higher education: Handbook of theory and research Vol. 7. (pp. 294-333). Bronx, NY: Agathon.

Wright, W. A., \& O’Neil M. C. (1995). Teaching improvement practices: International perspectives. In W. A. Wright and Associates, Teaching improvement practices (pp. 1-57). Bolton, MA: Anker. 